\title{
Marine snow, zooplankton and thin layers: indications of a trophic link from small-scale sampling with the Video Plankton Recorder
}

\author{
Klas O. Möller ${ }^{1, *}$, Michael St. John ${ }^{2,1}$, Axel Temming ${ }^{1}$, Jens Floeter ${ }^{1}$, Anne F. Sell ${ }^{3}$, \\ Jens-Peter Herrmann ${ }^{1}$, Christian Möllmann ${ }^{1}$ \\ ${ }^{1}$ Institute for Hydrobiology and Fisheries Science, Center for Earth System Research and Sustainability (CEN), \\ KlimaCampus, University of Hamburg, Grosse Elbstrasse 133, 22767 Hamburg, Germany \\ ${ }^{2}$ National Institute of Aquatic Resources at the Technical University of Denmark, Charlottenlund Castle, \\ 2920 Charlottenlund, Denmark \\ ${ }^{3}$ Johann Heinrich von Thünen-Institut, Institute of Sea Fisheries, Palmaille 9, 22767 Hamburg, Germany
}

\begin{abstract}
Marine aggregates of biogenic origin, known as marine snow, are considered to play a major role in the ocean's particle flux and may represent a concentrated food source for zooplankton. However, observing the marine snow-zooplankton interaction in the field is difficult since conventional net sampling does not collect marine snow quantitatively and cannot resolve so-called thin layers in which this interaction occurs. Hence, field evidence for the importance of the marine snow-zooplankton link is scarce. Here we employed a Video Plankton Recorder (VPR) to quantify small-scale (metres) vertical distribution patterns of fragile marine snow aggregates and zooplankton in the Baltic Sea during late spring 2002. By using this non-invasive optical sampling technique we recorded a peak in copepod abundance (ca. 18 ind. $1^{-1}$ ) associated with a pronounced thin layer ( 50 to $55 \mathrm{~m}$ ) of marine snow (maximum abundance of 28 particles $\mathrm{l}^{-1}$ ), a feature rarely resolved. We provide indirect evidence of copepods feeding on marine snow by computing a spatial overlap index that indicated a strong positively correlated distribution pattern within the thin layer. Furthermore we recorded images of copepods attached to aggregates and demonstrating feeding behaviour, which also suggests a trophic interaction. Our observations highlight the potential significance of marine snow in marine ecosystems and its potential as a food resource for various trophic levels, from bacteria up to fish.
\end{abstract}

KEY WORDS: Baltic Sea - Marine snow - Small-scale distribution - Thin layer · Trophic interactions · Video Plankton Recorder · Zooplankton

\section{INTRODUCTION}

Marine aggregates of biogenic origin, known as marine snow, are considered to play a major role in the ocean's particle flux (Alldredge \& Silver 1988, Graham et al. 2000, Stemmann \& Boss 2012) due to their high abundance and rapid sinking rates (Fowler \& Knauer 1986, Alldredge \& Silver 1988). This sinking of marine snow is a major mechanism of particulate carbon transport from the productive surface waters to the seafloor. Hence, marine snow represents an important contribution to carbon flux and sequestration. However, marine snow can also be a food resource for zooplankton, thereby contributing to the production of higher trophic levels (Dilling et al. 1998, Kiørboe 2011a,b). The link 
between marine snow and planktonic organisms is presently underappreciated due to their patchy distribution, which can occur even in a homogeneously mixed water column (Folt \& Burns 1999). The patchy distribution of plankton is a well-studied phenomenon and of great relevance for biological productivity, trophic interactions and food web dynamics in marine ecosystems (Mackas et al. 1985, Pinel-Alloul 1995). However, conventional net sampling cannot quantitatively sample marine snow and thus is unable to define small-scale distribution patterns. Recent advances in optical sampling methods, however, have allowed observations of plankton patches from microscale $(<1 \mathrm{~m})$ to small scale $(1$ to $10 \mathrm{~m})$ (e.g. Davis et al. 1992, Ashjian et al. 2001, Jacobsen \& Norrbin 2009).

Typical planktonic features on small vertical scales are thin layers, which are driven by physical and biological processes (McManus et al. 2003, Durham \& Stocker 2012). Physical processes identified to contribute to thin layers include water column stratification, vertical shear, and shearing by internal waves (Franks 1995, McManus et al. 2005). Often these thin layers are found in association with pycnoclines where the density gradient causes the accumulation of particles and plankton organisms (MacIntyre et al. 1995). Biological mechanisms bringing organisms to thin layers include diel vertical migration, predator avoidance, aggregation in food patches and mate search (e.g. Folt \& Burns 1999, Woodson \& MacManus 2007). Daly \& Smith (1993) suggested that physical forces dominate the formation of large-scale plankton patches while biotic processes become more important at smaller spatial scales. These abiotic and biotic processes lead to high concentrations of bacteria, phytoplankton, zooplankton and/or marine snow (Alldredge et al. 2002, McManus et al. $2003,2008)$ that can exceed the concentration of the surrounding environment by orders of magnitude. Hence, these layers may be regions of enhanced biological productivity and interactions (Sullivan et al. 2010a) and have been detected in a variety of marine systems including estuaries (Bochdansky \& Bollens 2009), coastal shelves (McManus et al. 2005) and the open ocean (Cowles et al. 1998). Conceivably thin layers may have an extensive impact on marine ecosystem dynamics, and the magnitude of their importance is just now beginning to be quantified (Alldredge et al. 2002, Durham \& Stocker 2012, Lyons \& Dobbs 2012).

Laboratory feeding studies and gut content analyses have provided evidence that marine snow is a potential food source for zooplankton (Dilling et al.
1998), even if dispersed phytoplankton cells are available (Dilling \& Brzezinski 2004). This observation might be especially important since larger crustacean zooplankton would be able to utilize nanoand microzooplankton that are colonizing marine snow aggregates and usually too small to be captured (Kiørboe 2001). However, little is known from in situ studies if aggregates are commonly grazed by zooplankton in the field (Kiørboe 2000, Jackson \& Checkley 2011).

Here we employed a Video Plankton Recorder (VPR) to quantify fragile marine snow aggregates and zooplankton and their relative small-scale vertical distribution. Using this non-invasive optical sampling technique we recorded a pronounced thin layer of marine snow and copepods associated with a density gradient, an association in a feature rarely observed. We provide indirect evidence of copepods feeding on marine snow aggregates due to a strong spatial overlap within the thin layer, which is supported by images of copepods being attached to aggregates.

\section{MATERIALS AND METHODS}

\section{Study area}

High-resolution images were obtained using the VPR during a spring bloom cruise in April 2002 on RV 'Alkor' in the Bornholm Basin in the central Baltic Sea (Fig. 1). The Baltic Sea is the largest brackish water area in the world. During summer a pronounced thermocline is established in the Bornholm Basin between 20 and $30 \mathrm{~m}$ depth while a strong halocline in 50 to $60 \mathrm{~m}$ depth separates the water column throughout the whole year (Matthäus \& Franck 1992). This strong physical stratification makes the central Baltic Sea an ideal area for investigations on thin layers.

\section{VPR}

The VPR (Seascan) is a modern optical underwater instrument, i.e. a digital underwater camera system towed by a research vessel. The VPR employed was equipped with a high-resolution digital camera (Pulnix TM-1040) that records 25 image frames $\mathrm{s}^{-1}$. We used a camera setting with a field of view of $0.7 \times$ $0.7 \mathrm{~cm}$, a focal depth of $3.00 \mathrm{~cm}$ and a calibrated image volume of $1.45 \mathrm{ml}$. The camera was set to the largest magnification (f-zoom) due to the small parti- 


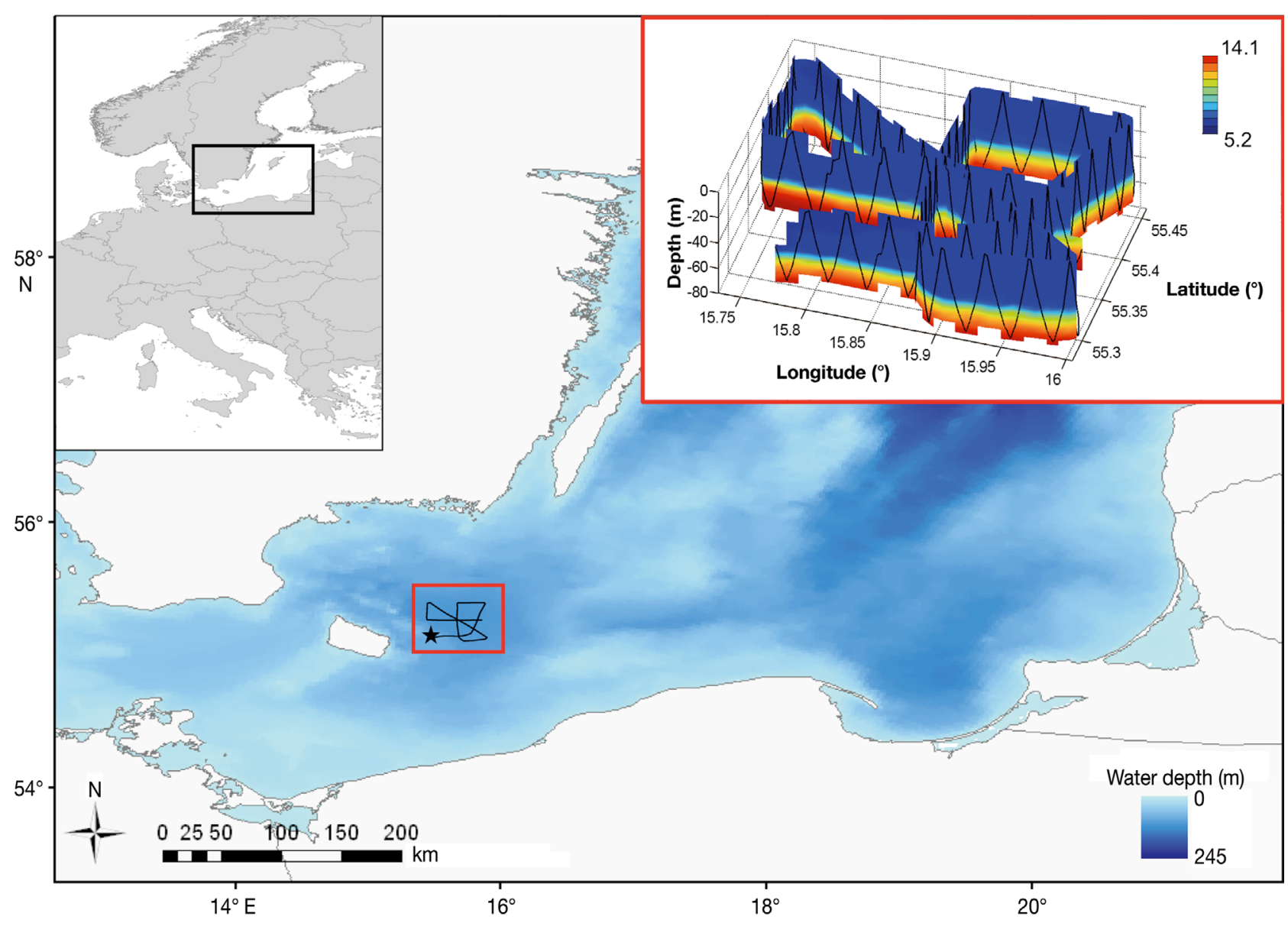

Fig. 1. The Baltic Sea with the study area in the Bornholm Basin marked by a red square; the black star indicates the net sampling location. Upper right panel: density profile $(\sigma$, color-coded) along the Video Plankton Recorder (VPR) tow track; the black line indicates the VPR tow-yos

cle and plankton sizes in the sampling area. This magnification was deemed suitable for imaging smallsized adult calanoid copepod species like Acartia spp., Temora longicornis and Pseudocalanus acuspes, known to dominate the mesozooplankton in the Baltic Sea (Möllmann et al. 2000). Illumination for the camera was provided by a strobe (Seascan, $20 \mathrm{~W}$ Hamamatsu xenon bulb) with a pulse duration of $1 \mu \mathrm{s}$ that was synchronized with the camera shutter. Additionally, the VPR was equipped with hydrographic and environmental sensors to measure temperature and salinity (CTD) (Falmouth Scientific) as well as fluorescence (Seapoint, model SCF).

The VPR was mounted on an equipment rack with a v-fin depressor and towed continuously from near bottom to near surface in an undulating way, to obtain data from the whole water column. In order to exclude the influence of turbulence in the ship's wake and to maintain a safe distance from the bottom, the sampled layer was limited to below $\sim 7 \mathrm{~m}$ from the surface and above $\sim 8 \mathrm{~m}$ from the bottom. We towed the VPR between 23:00 and 11:00 h covering the night/day transition. The gear was towed at $1.5 \mathrm{~m} \mathrm{~s}^{-1}$ (4 knots) and covered a distance of $115 \mathrm{~km}$ in total along a star-shaped transect (Fig. 1) with an hourly mean sampling volume of $130.4 \mathrm{l}$ (1565 l in total).

\section{Analysis and classification of images}

Recorded images and sensor data were sent in real time to an onboard unit via a fibre optic cable. Plankton and other particle images were extracted from each image frame as regions of interest (ROIs) using the Autodeck image analysis software (Seascan) and saved to the computer hard drive as TIFF files. Each ROI was tagged using a time stamp to allow merging with the hydrographic parameters that were written to a separate logfile. 


\section{Image classification}

All images were classified automatically following a method by $\mathrm{Hu} \&$ Davis (2006), an approach that includes an automatic correction step. This automatic correction step involves the computation of a confusion matrix from a set of training images in order to determine the detection of false positive rates. These rates are used to correct abundances estimated from the automatic classification results for each category. Aside from the manual sorting required to generate the initial training set of images, this dual-classification method is fully automatic and does not require subsequent manual correction of automatically sorted images. However, all images were also revised manually to avoid major misclassifications. Visual Plankton (Woods Hole Oceanographic Institution), an image processing and visualization application written in MATLAB (Mathworks), was used throughout the process of automatic classification. Once the ROIs were generated a representative and randomly picked subset of a sufficient number of Training ROIs (trROIs) (approximately 200, see Hu \& Davis 2006) was manually sorted into separate taxa or categories that were later used by the automatic classifier. The following step involved feature extraction algorithms that are used in image processing to detect, isolate and measure portions or shapes (features) of a digitised image. These features from the training ROIs were then used to create 2 classifiers in parallel. The first one was built from shape-based features and is called 'learning vector quantization neural network' (LVQ-NN). The second classifier was a 'support vector machine' (SVM) based on texturebased features of the same training samples. Detailed information about the operating modes of both is given elsewhere (Tang et al. 1998, Hu \& Davis 2006).

\section{Data handling}

Only those taxa and categories of the training samples that had a relatively large number of images and yielded high automatic classification accuracies were selected for automatic classification. Some portions of the extracted images were not in focus and hence not within the imaged volume. Those images were sorted out and put into the category 'blurry'. All copepod species were combined into the general 'copepod' category, as the present classification method cannot distinguish between all genera or species. Rare plankton taxa and those with low automatic classification accuracies were sorted into the 'other' category. This group was composed of larval fish, crustacean larvae, polychaetes, fish eggs, appendicularians, echinoderm larvae and gelatinous zooplankton (e.g. hydromedusae and ctenophores). Marine snow aggregates formed a category varying in shape and size and yielded a high classification accuracy due to their amorphous shapes and distinct texture. Representative example images of marine snow and copepods are given in Fig. 2.

\section{Additional net sampling}

Depth-resolved plankton net samples were collected in close proximity to the VPR transect (Fig. 1). We
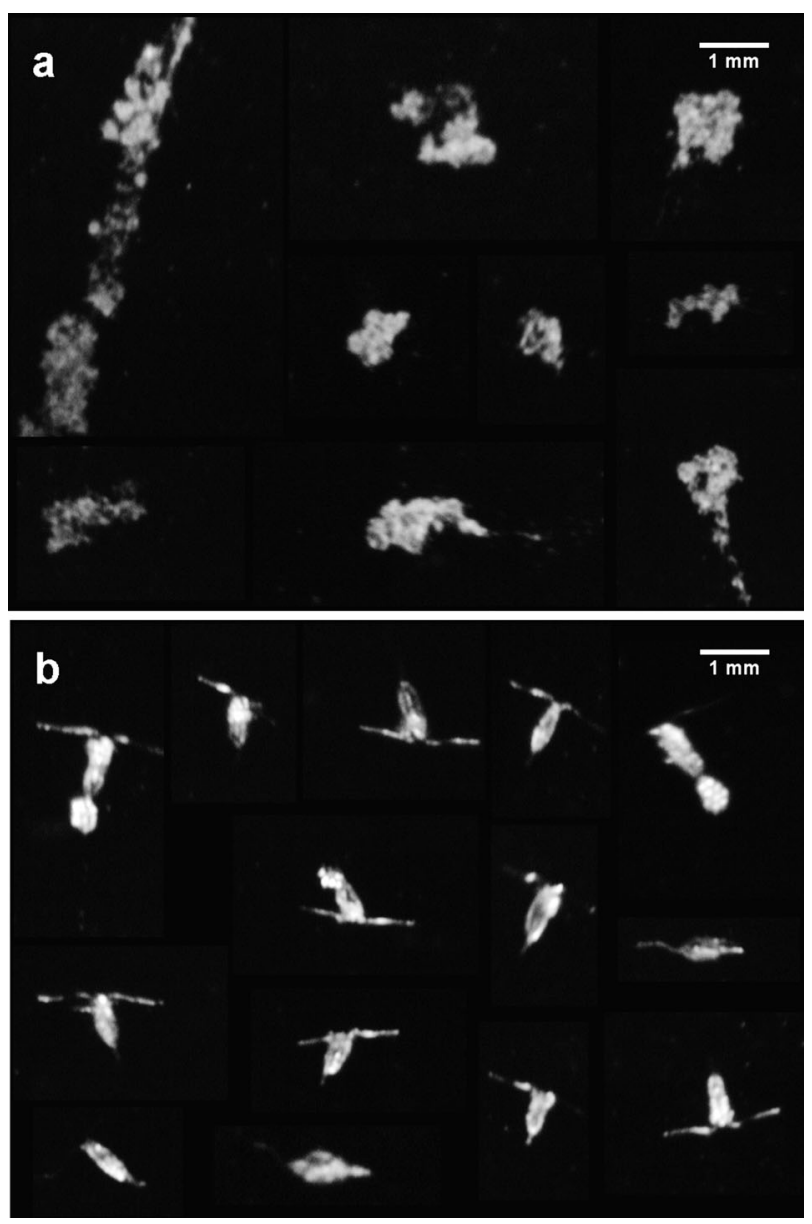

Fig. 2. Examples of VPR-derived images of (a) marine snow and (b) copepods. The copepod category comprises all species (e.g. Pseudocalanus acuspes females with egg sacs and Acartia spp.) 
used a Hydrobios Multinet (150 $\mu \mathrm{m}$ mesh size) for comparison and ground-truthing of the VPR data and to obtain taxonomic information on the species level for copepods. Samples were taken between the surface and close to the bottom $(\sim 70 \mathrm{~m})$ in stacked $10 \mathrm{~m}$ intervals and were immediately fixed in a boraxbuffered formaldehyde-seawater solution (4\% final formaldehyde concentration) for later analysis. Due to a lack of direct overlap between taxonomic categories (because of different taxonomic identification levels and sensitivity to fragile organisms) of net samples and VPR data, a quantitative comparison was only possible for the VPR-derived copepod category. Net samples were sorted manually to copepod species and stage (nauplii, copepodite stages C1 to C5 and adult males or females). Copepodites and adult copepods of all species were grouped together for comparison. Nauplii data were not used for the analysis.

\section{Spatial overlap index}

To assess the vertical overlap between copepods and marine snow aggregates in the water column we employed the spatial overlap index $(O)$ described by Williamson \& Stoeckel (1990):

$$
O=\frac{\sum_{z=1}^{m}\left(N_{z} \times n_{z}\right) m}{\sum_{z=1}^{m}\left(N_{z}\right) \times \sum_{z=1}^{m}\left(n_{z}\right)}
$$

where $z$ represents the depth strata, $m$ is number of depth points sampled, $N_{z}$ is the density of copepods at a given depth and $n_{z}$ is the density of marine snow aggregates at a given depth. An overlap index of $<1$ indicates spatial separation between the copepod and marine snow, an index $=1$ indicates a homogeneous distribution, while values of $>1$ indicate an aggregation of copepods and marine snow in certain strata of the water column.

Overlap indices of cumulative abundances for copepods and marine snow were determined for every $2 \mathrm{~h}$ time step along the VPR tow track. There is no statistical test to evaluate the deviation of observed overlap from random expectation. Hence, in order to assess and test for variations in the bihourly spatial overlap along the VPR tow track we computed the overlap index for each 10 min time step, corresponding to one complete up and down cast.

\section{RESULTS}

\section{Hydrography}

As background information for our investigations on the small-scale distribution of marine snow and mesozooplankton we recorded the hydrographic environment along the VPR transect. We found the vertical distribution of temperature, salinity and density to represent a typical spring situation in the central Baltic Sea (Fig. 3), which included a surface mixed layer with a mean temperature of $4.5^{\circ} \mathrm{C}$ that was observed down to $50 \mathrm{~m}$. No thermocline was recorded in the upper layer, but slightly elevated temperatures near the surface indicated the seasonal warming of surface waters. However, a thermocline

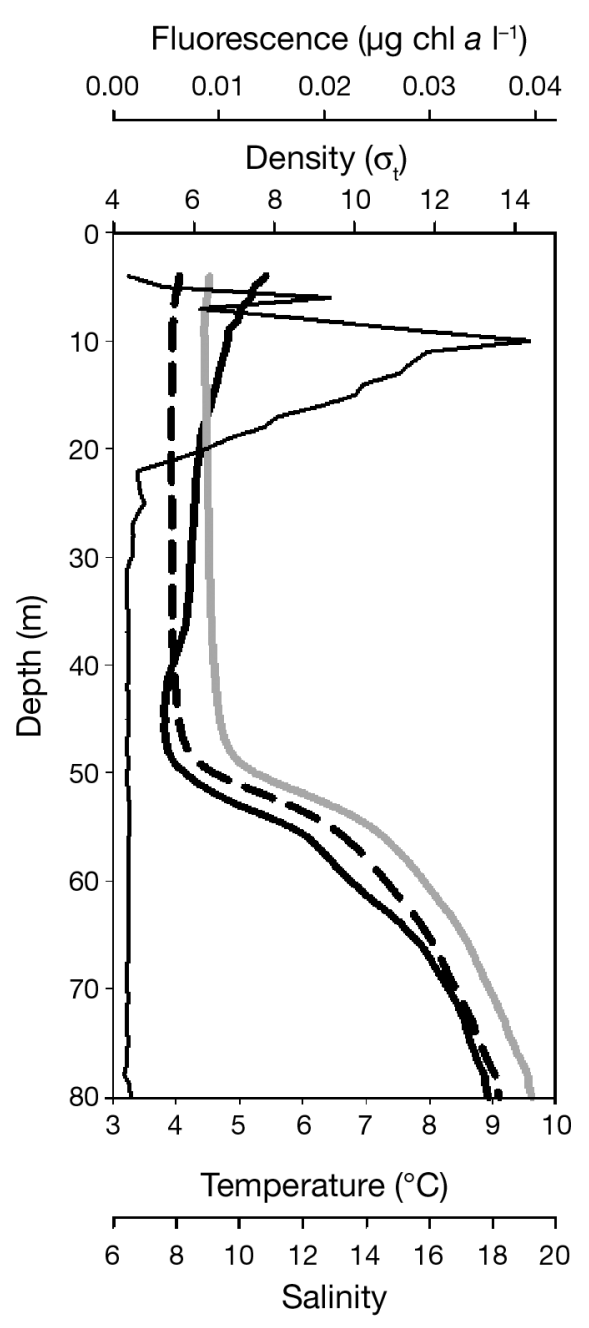

Fig. 3. Environmental data: vertical profiles of temperature (bold black line), salinity (black dashed line), density (grey line) and relative fluorescence (thin black line), averaged over the whole VPR tow track for each $1 \mathrm{~m}$ depth interval 
separated the upper water layer from the winter deep water where temperatures increased to $9^{\circ} \mathrm{C}$. The deep thermocline matched exactly with the permanent halocline, where salinity increased with depth from 8 to a maximum of 18. Together the thermocline and the halocline represented a strong density gradient, i.e. a pycnocline.

\section{Phytoplankton}

We recorded the chlorophyll a ( $\mathrm{chl}$ a) concentration as an index of the phytoplankton biomass by performing fluorescence measurements (Fig. 3). Due to our sampling scheme VPR measurements were not performed close to the surface. However, we observed phytoplankton primarily in the uppermost sampling stratum closest to the surface and not deeper than $20 \mathrm{~m}$. Mean values of relative chl a were generally low (max. $0.04 \mu \mathrm{g} \mathrm{l}^{-1}$ ) and peak abundances were patchy along the transect (max. $\left.0.4 \mu \mathrm{g} \mathrm{l}^{-1}\right)$.

\section{Marine snow}

Marine snow aggregates were the second most abundant category recorded by the VPR next to copepods. The particle size spectra ranged from
0.2 to $7 \mathrm{~mm}$ in diameter with the highest abundances in the size class of $\sim 0.5 \mathrm{~mm}$. Fine-scale sampling with the VPR revealed a dense thin layer of marine snow aggregates at the pycnocline between 50 and $55 \mathrm{~m}$ depth (Fig. 4a). This thin marine snow layer was observed to occur over the whole transect with peak abundances of marine snow aggregates of 28 particles $1^{-1}$. Background aggregate concentrations in the water column varied between 5 and 8 particles $1^{-1}$ with a mean $( \pm \mathrm{SD})$ abundance of $6.4 \pm 0.5$ particles $1^{-1}$. Less dense patches of marine snow not related to the pycnocline were observed at some locations in the upper mixed layer.

Visual examination of our marine snow images identified the phytoplankton origin of most aggregates, with many of the larger aggregates having the characteristic rod shape of diatoms. Additionally, appendicularians might have contributed to the marine snow production, since they produce houses that, once discarded, look like diatom flocks. Smaller and more abundant aggregates had a mucoid matrix including senescent diatom cells, detrital material and, due to the high abundance of copepods, probably also copepod exoskeletons as well as fecal pellets. We assume the absence of a fluorescence signal within the thin layer observed in our study to be due to the decay of phytoplankton cells. This could also explain the presence of an amorphous and flocculent film visible on all images. Furthermore, we observed
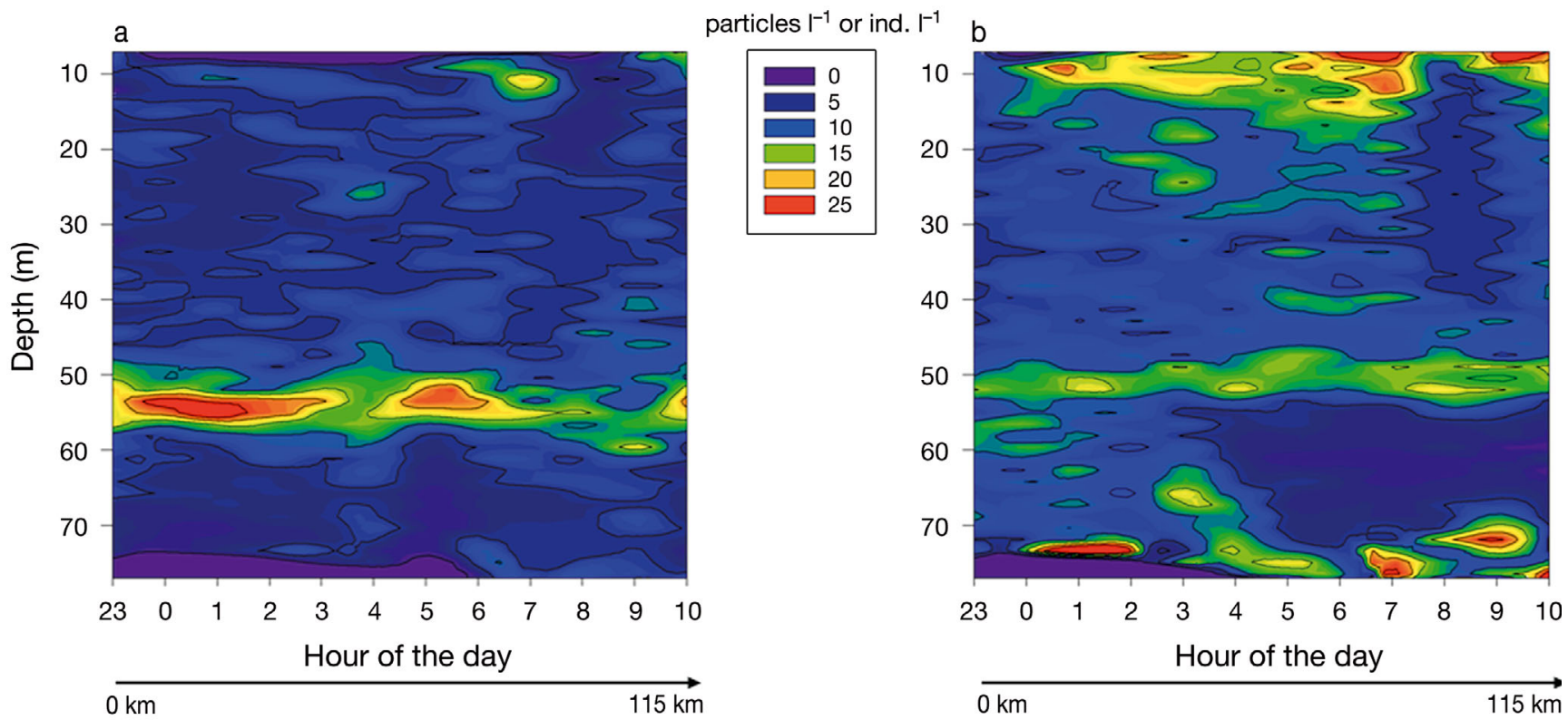

Fig. 4. Contour plots showing the average hourly depth distribution and abundance of (a) marine snow (particles $\mathrm{l}^{-1}$ ) and (b) copepods (ind. $\mathrm{l}^{-1}$ ) recorded with the Video Plankton Recorder (VPR); the black arrow indicates the cumulative distance travelled by the ship along the tow track 
no major changes in marine snow abundance or particle size that could be attributed to diel influences during night and day transition.

\section{Mesozooplankton}

Copepods were the dominant group comprising $60 \%$ of all mesozooplankton organisms classified. Additionally we recorded approximately $30 \%$ appendicularians and $10 \%$ gelatinous organisms (comprising small hydromedusa and ctenophores) in the identified mesozooplankton category. We observed a vertical maximum in abundance of copepods in the upper surface layer (28.2 ind. $\mathrm{l}^{-1}$ ) and close to the bottom (23.4 ind. $\left.\mathrm{l}^{-1}\right)$, and a distinct peak within the pycnocline (18.2 ind. $\mathrm{l}^{-1}$ ) (Fig. 4b). Background copepod concentrations between those peak abundances in the water column varied between 5 and 9 ind. $\mathrm{l}^{-1}$ with a mean abundance of $7.9 \pm 1.0$ ind. $\mathrm{l}^{-1}$. The abundance peak in the pycnocline was stable during most of the transect, with high copepod abundances overlapping with the marine snow thin layer. Dense patches of copepods were also found close to the bottom as well as near the surface. In comparison with the deep water aggregations these patches were more heterogeneous in distribution and less pronounced, while the surface aggregations ten- ded to have a more widespread vertical distribution and were more patchy horizontally. There was no indication of diel changes in the vertical copepod distribution.

We used conventional net sampling and manual sorting to evaluate the copepod species composition not resolved by the VPR (Fig. 5a). The copepod community was dominated by Acartia spp., Temora longicornis, Pseudocalanus acuspes and Oithona similis. Copepods displayed species-specific vertical distributions, which allowed a mapping of species to the different vertical peaks in the copepod category sampled by the VPR. Acartia spp. and T. longicornis dominated the upper layer $<30 \mathrm{~m}$ depths, while $P$. acuspes and $O$. similis were found in the pycnocline and in aggregations in the deep water above the bottom.

A comparison of the 2 sampling techniques revealed strong differences in abundance values recorded and in the ability to resolve vertical distribution patterns (Fig. 5). For this purpose copepod abundance values sampled with the VPR along the tow track were averaged in $1 \mathrm{~m}$ depth bins. All copepod species sampled with the Multinet were grouped into one abundance category to match the VPR sampling, but, due to the nature of the sampling gear, in $10 \mathrm{~m}$ depth bins only. Mean abundances sampled with the VPR were generally higher (max. 13.5 ind.

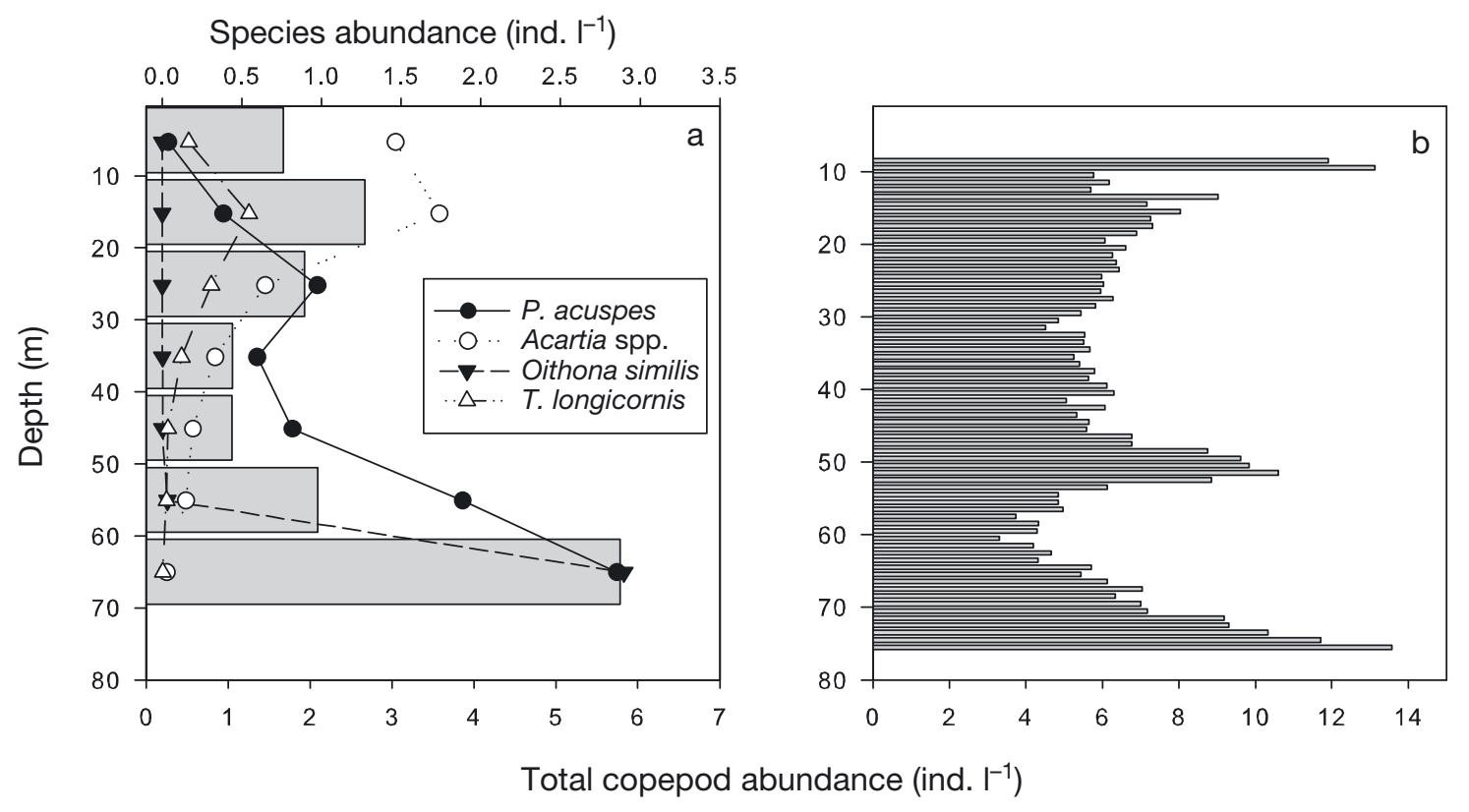

Fig. 5. Vertical copepod distribution patterns: (a) total copepod abundance combining all species in one category in $10 \mathrm{~m}$ depth bins (from 0 to $70 \mathrm{~m}$ ), and species-specific depth distribution of copepods (including adults and copepodite stages) sampled with the Multinet; (b) copepod abundance sampled with the Video Plankton Recorder (VPR) averaged over the whole tow track in $1 \mathrm{~m}$ depth bins (from 8 to $76 \mathrm{~m}$ depths). P.: Pseudocalanus; T.: Temora 
$\mathrm{l}^{-1}$ ) than with the Multinet (max. 5.8 ind. $\mathrm{l}^{-1}$ ). As expected the vertical distribution pattern showed clear differences as well. The fine-scale resolution of the VPR profile allowed discrimination of the copepod layer at 50 to $55 \mathrm{~m}$, while this feature could not be observed with the coarse vertical resolution of the Multinet sampling.

\section{Indications for marine snow-mesozooplankton interaction}

As an indication of the feeding interaction between copepods and marine snow, we calculated an index of their vertical overlap. Overlap indices for marine snow and copepods ranged from 1.04 to 1.51 along the whole tow track, indicating a permanent positively correlated distribution pattern (Fig. 6). Peak concentrations of marine snow aggregates and high abundances of copepods coincided within a vertical narrow band along the pycnocline. Because there was no indication of diel changes in the abundance and distribution of copepods and marine snow, a stable overlap was observed. Only minor variations were observed in the overlap index for single up and down casts of the VPR between index values of 0.99 and 1.6.

A portion (approx. $5 \%$ ) of the marine snow aggregate images obtained with the VPR showed copepods directly attached to the aggregates, suggesting an active feeding behaviour. However, this estimate may be low due to occlusion of copepods by aggre-

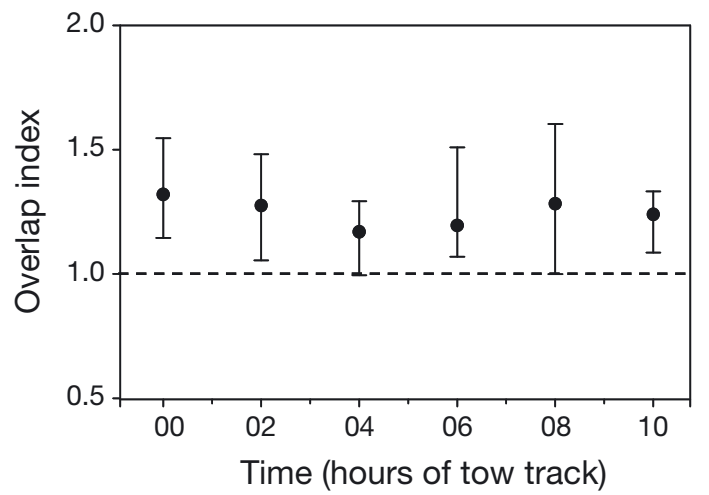

Fig. 6. Spatial overlap of marine snow and copepods: black dots represent bi-hourly estimates of the Williamson spatial overlap index during the sampling period; error bars show minimum and maximum variations of the overlap index for each 20 min time step; overlap indices $<1$ indicate spatial segregation between the copepod and marine snow; overlap indices $=1$ indicate that copepods and/or marine snow are uniformly distributed in the water column; overlap indices $>$ 1 (black dashed line) indicate aggregation of copepods and marine snow in certain strata of the water column gates and the ROI extraction method. Furthermore, many of those images that were in focus and of high quality allowed species identification. Most of these images showed Pseudocalanus acuspes with its antennae in feeding position (Broughton \& Lough 2006) suggesting active feeding by copepods on marine snow (Fig. 7). Feeding behaviour of Temora longicornis could be identified on a few images as well.

\section{DISCUSSION}

\section{Marine snow occurrence}

In this study we quantified the abundance of fragile marine snow aggregates as well as their sizes. We evaluated the results through a comprehensive literature review on studies quantifying marine snow aggregates (Table 1). Our review revealed a large range of particle abundance and sizes. Generally, several factors influence the quantification of marine snow metrics in the field and can explain the variability between studies. For example, variability in particle concentrations can be the result of the sampling location or sampling technique. Many previous studies are based on quantitative observations by divers, which are often limited to particles readily visible ( $\geq 3 \mathrm{~mm}$ ) and restricted to the upper surface layer (Lampitt et al. 1993b). Technical advances within the last 2 decades have led to an increased number of data sets that have been assessed by optical sampling methods and generally tend to result in decreasing aggregate sizes. Furthermore, size estimates based on in situ measurements with camera

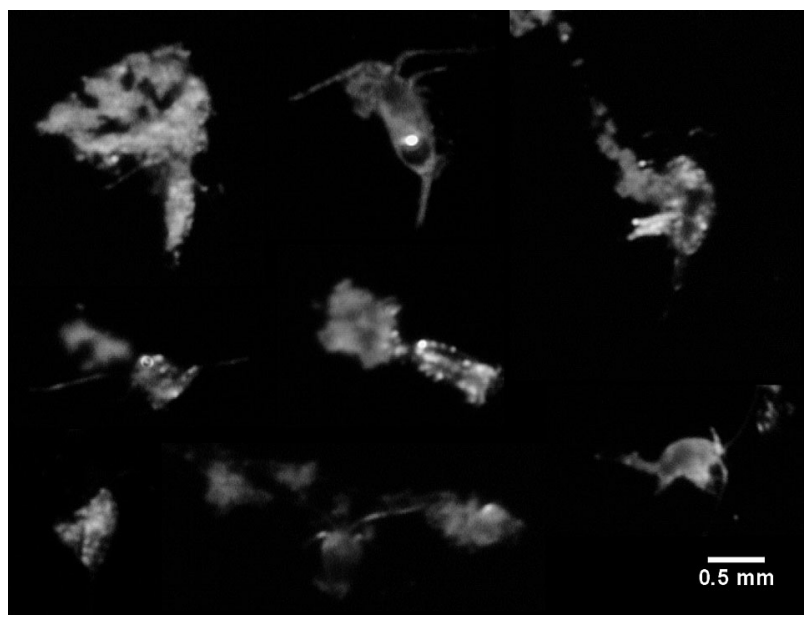

Fig. 7. Example of VPR-derived images of copepods attached to marine snow, indicating a trophic interaction 


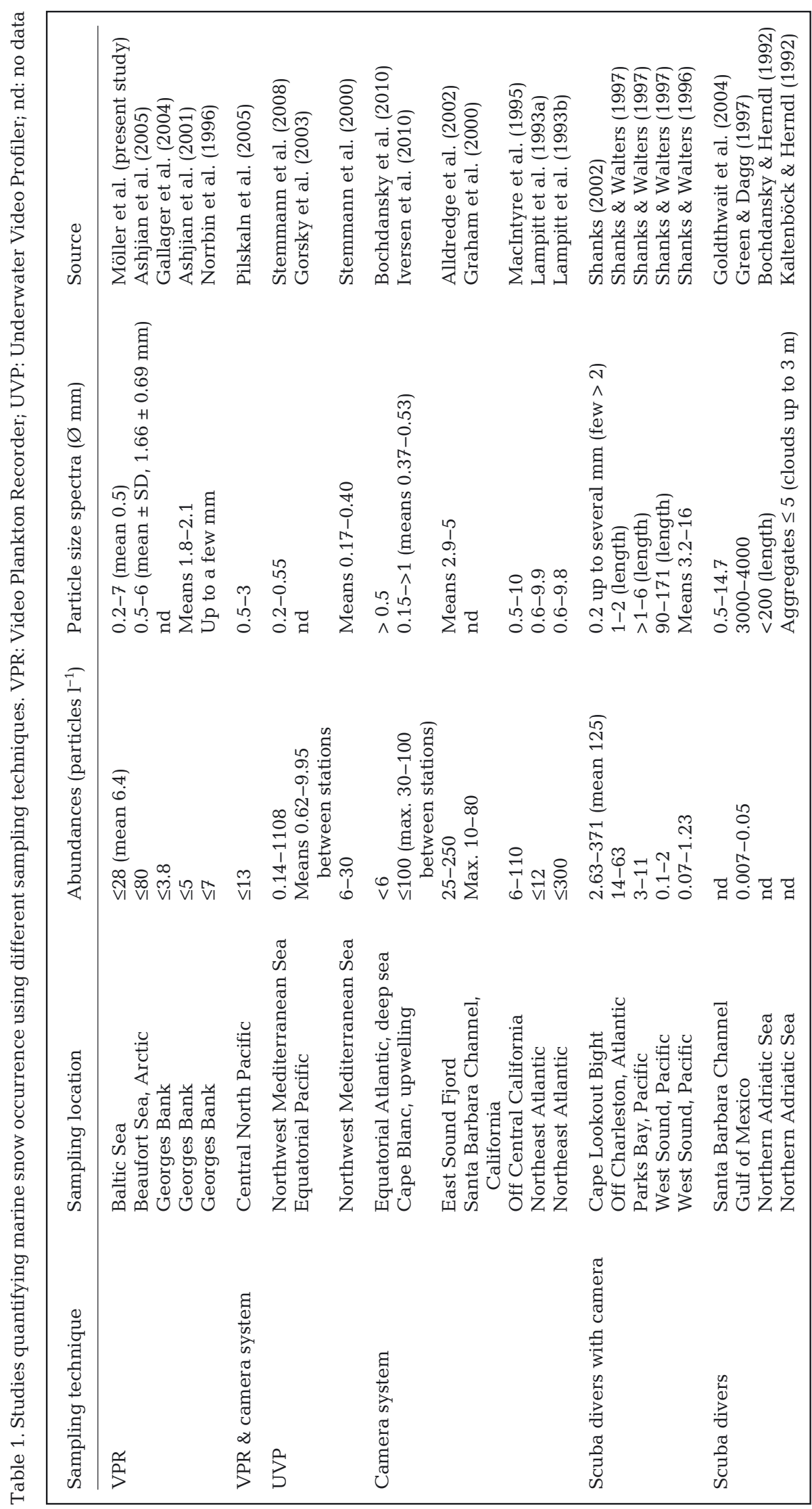

systems always depend on the respective field of view, which may explain differences between particular studies. Our estimates of particle abundance are in the upper range of studies using the VPR, which all displayed similar particle size ranges. Similar values were also recorded using Underwater Video Profilers. Based on the literature review, we consider our marine snow abundance estimates as reliable.

\section{Mesozooplankton abundance and distribution}

A comparison of copepod abundances revealed estimates derived by the VPR to be generally more than 2 -fold higher than those obtained with the Multinet. Similar results have been reported by Benfield et al. (1996) and Broughton \& Lough (2006) when comparing zooplankton abundances obtained with a VPR and a MOCNESS (Multiple Opening/Closing Net and Environmental Sampling System) sampler. Differences between the 2 gear types are probably due to different sampling efficiencies for earlier copepodite stages as well as smaller copepod species such as Oithona similis, which are typically underrepresented in net samples due to net extrusion and/or avoidance (Gallienne \& Robins 2001, Broughton \& Lough 2006).

The high spatial and temporal resolution of sampling with the VPR relative to the Multinet was critical for resolving vertical thin layers. Clearly our net sampling was not able to resolve the pronounced small-scale abundance peak in the halocline, which was only visible in the VPR data. However, the strength of the 
Multinet data is in the provision of abundance information on the species level. Manual analysis of Multinet samples allowed a clear attribution of the dominant copepod species to the layers of high copepod abundance observed by the VPR. Similar to earlier studies (Hansen et al. 2006), we found Acartia spp. and Temora longicornis inhabiting the upper water column. Both species have a preference for high water temperatures and low salinities (Holste \& Peck 2006, Holste et al. 2009), and hence may exploit the chl a maximum in the upper water layer. Conversely, Pseudocalanus acuspes and Oithona similis are marine species with preferences for high salinities and low temperatures (Hansen et al. 2004, Renz \& Hirche 2006), hence dominate the zooplankton abundance in the deep and saline marine snow layer. Due to its ontogenetic vertical distribution, the vertical distribution of $P$. acuspes showed a minor abundance peak at $\sim 25 \mathrm{~m}$ depth, which can be attributed to younger copepodite stages (Renz \& Hirche 2006).

\section{Thin layers of marine snow and mesozooplankton}

The formation of thin layers of passive particles is controlled by physical and biological factors (Sullivan et al. 2010b). For example marine snow particles have been identified to form thin layers at strong density gradients due to reduced sinking rates (Alldredge et al. 2002). Processes leading to aggregations of motile planktonic organisms in thin layers are much more complex. They include active swimming, sexual reproduction, predator avoidance, food availability and responses to chemical or physical cues (Dekshenieks et al. 2001, McManus et al. 2003, 2005, Gallager et al. 2004, Malkiel et al. 2006, Benoit-Bird et al. 2010, Holliday et al. 2010).

Although the mechanisms described above have substantial consequences for the ecological importance of thin layers, they have to a large extent remained untested in the field (Benoit-Bird et al. 2009). Generally, the existence of thin vertical layers has been rarely investigated, which is due to the low sampling efficiency of traditional net sampling for marine snow and the generally low ability of this method to resolve small-scale distribution patterns (Widder et al. 1999, Alldredge et al. 2002, Jacobsen \& Norrbin 2009). Studies using optical and acoustical instruments have only recently started to quantitatively describe thin layers of marine snow at density gradients (Alldredge et al. 2002, McManus et al. 2003). In the present study, we describe an intense thin layer of marine snow aggregates associated with a strong vertical density gradient in the permanent halocline typical for a deep Baltic basin, using results from small-scale sampling with a VPR. In contrast to earlier studies (Cheriton et al. 2007, Sevadjian et al. 2010), we found this layer of marine snow aggregates persisting throughout our whole sampling track, most likely due to the stability of the halocline.

Furthermore, we observed a thin layer of copepods directly attached to marine snow aggregates that showed signs of typical feeding behaviour. Hence, we suggest that copepods actively respond to dense marine snow aggregations with the goal to use them as a food source. A number of laboratory experiments have shown that copepods are able to detect and exploit food patches in thin layers (Tiselius 1992). However, field observations of zooplankton behaviour in relation to thin layers of marine snow, such as in the present study, are still rare. Previous field studies mainly investigated zooplankton thin layers acoustically (e.g. McManus et al. 2003, Benoit-Bird et al. 2009, Holliday et al. 2010). However, these studies were not able to investigate the species composition in these layers, which is an important issue as behavioural responses are often species-specific. Alldredge et al. (2002), using a camera system, observed high densities of planktonic organisms above and below a thin layer of marine snow. They suggested that most macrozooplankton taxa avoid the thin layer because of very high marine snow abundances that potentially lead to clogging of their delicate feeding appendages. In agreement with our observations Malkiel et al. (2006) reported elevated abundances of calanoid copepods in water layers with maximum concentrations of marine snow. However, they interpreted this pattern as predator avoidance behaviour, since high concentrations of large detritus particles may provide shelter from visual predators (Malkiel et al. 2006). Based on our high-resolution imaging study using the VPR, we suggest that zooplanktonic copepods aggregate in thin layers as a response to a concentrated food source of marine snow.

\section{Trophic interactions between marine snow and zooplankton}

The key finding of this study is a strong association of copepods showing signs of typical feeding behaviour with a thin layer of marine snow. Our results support earlier laboratory and field studies that provide direct evidence of feeding interactions between marine snow and euphausiids (Dilling et 
al. 1998, Dilling \& Brzezinski 2004), ostracods and amphipods (Lampitt et al. 1993b), as well as copepods (Steinberg 1995, Koski et al. 2007, Chen et al. 2010, Wilson \& Steinberg 2010). A few studies provided, as we have here, indirect evidence of feeding interactions through close spatial associations between zooplankton and marine snow aggregates (Shanks \& Edmondson 1990, Bochdansky \& Herndl 1992, Green \& Dagg 1997, Shanks \& del Carmen 1997, Malkiel et al. 2006). Despite these indications of a trophic interaction, there still remains the question whether marine snow is a viable food source for zooplankton. There is still little information on the trophodynamic importance of marine snow in marine ecosystems since these aggregates are difficult to quantify both in the lab and the field. In our study, marine snow particles consisted primarily of mucoid detritus derived from phytoplankton cells, which usually represents a viable food source for copepods (Dilling et al. 1998). In the Baltic Sea, feeding on marine snow in the halocline may even be crucial for the survival of copepod populations. In or below the halocline of the deep Baltic basins no primary production occurs, and copepod species such as Pseudocalanus acuspes and Oithona similis, which need the elevated salinities in deeper waters (Hansen et al. 2004, 2006, Renz \& Hirche 2006), experience comparable conditions as zooplankton residing in the mesopelagic zone of the open ocean. At this depth nutrition must be obtained to a large degree via feeding on sinking aggregates (e.g. Steinberg 1995). Lipid biomarker studies support this hypothesis and show that Baltic $P$. acuspes is an opportunistic feeder, feeding mainly on sinking algae, detritus and microzooplankton (Peters et al. 2006). Furthermore, these investigations suggest that ciliates, which generally show elevated concentrations on marine snow aggregates (Silver et al. 1984, Lombard et al. 2010), have a high relevance in the food spectrum of $P$. acuspes (Peters et al. 2006).

Our observations support the hypothesis that marine snow aggregates are an important food source for mesozooplankton, especially in stratified regions such as the central Baltic Sea. Furthermore, marine snow may have an important function in the ecosystem as an additional food source for benthic suspension feeders (Newell et al. 2005) and possibly larval and juvenile fish (Larson \& Shanks 1996, Green \& Dagg 1997). Our observations highlight the significance of marine snow in marine ecosystems and its potential as a food source for various trophic levels, from bacteria up to fish.
Acknowledgements. We thank the captain and crew of the RV 'Alkor' for support during the cruise. Special thanks go to Dr. S. Gallager and Dr. C. Davis for their assistance at sea. We express our special gratitude to Dr. C. Davis for generously sharing knowledge on the software Visual Plankton and support during the analysis of data sets derived from the Video Plankton Recorder (VPR). This study benefited greatly from the support and help of Dr. R. Campbell and Dr. M. Holtegaard Nielsen. Furthermore, we thank 2 anonymous reviewers for their helpful comments and suggestions. This study was supported by the European Commission's 7th Framework Programmes 'Marine Ecosystem Evolution in a Changing Environment', (MEECE, No. 212085); 'EU Basin-scale Analysis, Synthesis \& Integration' (EURO-BASIN, no. 264933) and was conducted during the GLOBECGermany project funded by the German Ministry for Education and Research (BMBF). The German Science Foundation (DFG) is acknowledged for funding the VPR.

\section{LITERATURE CITED}

Alldredge AL, Silver MW (1988) Characteristics, dynamics and significance of marine snow. Prog Oceanogr 20: $41-82$

Alldredge AL, Cowles TJ, MacIntyre S, Rines JEB and others (2002) Occurrence and mechanisms of formation of a dramatic thin layer of marine snow in a shallow Pacific fjord. Mar Ecol Prog Ser 233:1-12

Ashjian CJ, Davis CS, Gallager SM, Alatalo P (2001) Distribution of plankton, particles, and hydrographic features across Georges Bank described using the Video Plankton Recorder. Deep-Sea Res II 48:245-282

Ashjian CJ, Gallager SM, Plourde S (2005) Transport of plankton and particles between the Chukchi and Beaufort Seas during summer 2002, described using a Video Plankton Recorder. Deep-Sea Res II 52:3259-3280

> Benfield MC, Davis CS, Wiebe PH, Gallager SM, Lough RG, Copley NJ (1996) Video Plankton Recorder estimates of copepod, pteropod and larvacean distributions from a stratified region of Georges Bank with comparative measurements from a MOCNESS sampler. Deep-Sea Res II 43:1925-1945

Benoit-Bird KJ, Cowles TJ, Wingard CE (2009) Edge gradients provide evidence of ecological interactions in planktonic thin layers. Limnol Oceanogr 54:1382-1392

Benoit-Bird KJ, Moline MA, Waluk CM, Robbins IC (2010) Integrated measurements of acoustical and optical thin layers I: vertical scales of association. Cont Shelf Res 30: $17-28$

Bochdansky AB, Bollens SM (2009) Thin layer formation during runaway stratification in the tidally dynamic San Francisco Estuary. J Plankton Res 31:1385-1390

Bochdansky AB, Herndl GJ (1992) Ecology of amorphous aggregations (marine snow) in the Northern Adriatic Sea. III. Zooplankton interactions with marine snow. Mar Ecol Prog Ser 87:135-146

> Bochdansky AB, van Aken HM, Herndl GJ (2010) Role of macroscopic particles in deep-sea oxygen consumption. Proc Natl Acad Sci USA 107:8287-8291

> Broughton EA, Lough RG (2006) A direct comparison of MOCNESS and Video Plankton Recorder zooplankton abundance estimates: possible applications for augmenting net sampling with video systems. Deep-Sea Res II 53: 2789-2807 
Chen MR, Ka S, Hwang JS (2010) Diet of the copepod Calanus sinicus Brodsky, 1962 (Copepoda, Calanoida, Calanidae) in northern coastal waters of Taiwan during the Northeast Monsoon period. Crustaceana 83:851-864

Cheriton OM, McManus MA, Holliday DV, Greenlaw CF, Donaghay PL, Cowles TJ (2007) Effects of mesoscale physical processes on thin zooplankton layers at four sites along the west coast of the US. Estuar Coasts 30: 575-590

- Cowles TJ, Desiderio RA, Carr ME (1998) Small-scale planktonic structure: persistence and trophic consequences. Oceanography 11:4-9

- Daly KL, Smith WO Jr (1993) Physical-biological interactions influencing marine plankton production. Annu Rev Ecol Syst 24:555-585

> Davis CS, Gallager SM, Solow AR (1992) Microaggregations of oceanic plankton observed by towed video microscopy. Science 257:230-232

> Dekshenieks MM, Donaghay PL, Sullivan JM, Rines JEB, Osborn TR, Twardowski MS (2001) Temporal and spatial occurrence of thin phytoplankton layers in relation to physical processes. Mar Ecol Prog Ser 223:61-71

> Dilling L, Brzezinski MA (2004) Quantifying marine snow as a food choice for zooplankton using stable silicon isotope tracers. J Plankton Res 26:1105-1114

> Dilling L, Wilson J, Steinberg D, Alldredge AL (1998) Feeding by the euphausiid Euphausia pacifica and the copepod Calanus pacificus on marine snow. Mar Ecol Prog Ser 170:189-201

> Durham WM, Stocker R (2012) Thin phytoplankton layers: characteristics, mechanisms, and consequences. Annu Rev Mar Sci 4:177-207

> Folt CL, Burns CW (1999) Biological drivers of zooplankton patchiness. Trends Ecol Evol 14:300-305

Fowler SW, Knauer GA (1986) Role of large particles in the transport of elements and organic compounds through the oceanic water column. Prog Oceanogr 16:147-194

> Franks PJS (1995) Thin layers of phytoplankton: a model of formation by near-inertial wave shear. Deep-Sea Res I 42:75-91

> Gallager SM, Yamazaki H, Davis CS (2004) Contribution of fine-scale vertical structure and swimming behavior to formation of plankton layers on Georges Bank. Mar Ecol Prog Ser 267:27-43

> Gallienne CP, Robins DB (2001) Is Oithona the most important copepod in the world's oceans? J Plankton Res 23: 1421-1432

> Goldthwait S, Yen J, Brown J, Alldredge AL (2004) Quantification of marine snow fragmentation by swimming euphausiids. Limnol Oceanogr 49:940-952

> Gorsky G, Le Borgne R, Picheral M, Stemmann L (2003) Marine snow latitudinal distribution in the equatorial Pacific along 180 degrees. J Geophys Res 108:8146, doi: 10.1029/2001JC001064

> Graham WM, MacIntyre S, Alldredge AL (2000) Diel variations of marine snow concentration in surface waters and implications for particle flux in the sea. Deep-Sea Res I 47:367-395

Green EP, Dagg MJ (1997) Mesozooplankton associations with medium to large marine snow aggregates in the northern Gulf of Mexico. J Plankton Res 19:435-447

Hansen FC, Möllmann C, Schütz U, Hinrichsen HH (2004) Spatio-temporal distribution of Oithona similis in the Bornholm Basin (Central Baltic Sea). J Plankton Res 26: 659-668
Hansen FC, Möllmann C, Schütz U, Neumann T (2006) Spatio-temporal distribution and production of calanoid copepods in the central Baltic Sea. J Plankton Res 28: 39-54

> Holliday DV, Greenlaw CF, Donaghay PL (2010) Acoustic scattering in the coastal ocean at Monterey Bay, CA, USA: fine-scale vertical structures. Cont Shelf Res 30: 81-103

> Holste L, Peck MA (2006) The effects of temperature and salinity on egg production and hatching success of Baltic Acartia tonsa (Copepoda: Calanoida): a laboratory investigation. Mar Biol 148:1061-1070

Holste L, St. John MA, Peck MA (2009) The effects of temperature and salinity on reproductive success of Temora longicornis in the Baltic Sea: a copepod coping with a tough situation. Mar Biol 156:527-540

> Hu Q, Davis CS (2006) Accurate automatic quantification of taxa-specific plankton abundance using dual classification with correction. Mar Ecol Prog Ser 306:51-61

Iversen MH, Nowald N, Ploug H, Jackson GA, Fischer G (2010) High resolution profiles of vertical particulate organic matter export off Cape Blanc, Mauritania: degradation processes and ballasting effects. Deep-Sea Res I 57:771-784

> Jackson GA, Checkley DM Jr (2011) Particle size distributions in the upper $100 \mathrm{~m}$ water column and their implications for animal feeding in the plankton. Deep-Sea Res I 58:283-297

Jacobsen HP, Norrbin MF (2009) Fine-scale layer of hydromedusae is revealed by video plankton recorder (VPR) in a semi-enclosed bay in northern Norway. Mar Ecol Prog Ser 380:129-135

Kaltenböck E, Herndl GJ (1992) Ecology of amorphous aggregations (marine snow) in the Northern Adriatic Sea. IV. Dissolved nutrients and the autotrophic community associated with marine snow. Mar Ecol Prog Ser 87: $147-159$

Kiørboe T (2000) Colonisation of marine snow aggregates by invertebrate zooplankton: abundance, scaling, and possible role. Limnol Oceanogr 45:479-484

Kiørboe T (2001) Formation and fate of marine snow: smallscale processes with large-scale implications. Sci Mar 65(Suppl 2):57-71

Kiørboe T (2011a) What makes pelagic copepods so successful? J Plankton Res 33:677-685

Kiørboe T (2011b) How zooplankton feed: mechanisms, traits and trade-offs. Biol Rev Camb Philos Soc 86: 311-339

Koski M, Möller EF, Maar M, Visser AW (2007) The fate of discarded appendicularian houses: degradation by the copepod, Microsetella norvegica, and other agents. J Plankton Res 29:641-654

> Lampitt RS, Hillier WR, Challenor PG (1993a) Seasonal and diel variation in the open ocean concentration of marine snow aggregates. Nature 362:737-739

> Lampitt RS, Wishner KF, Turley CM, Angel MV (1993b) Marine snow studies in the Northeast Atlantic Ocean: distribution, composition and role as a food source for migrating plankton. Mar Biol 116:689-702

> Larson ET, Shanks AL (1996) Consumption of marine snow by two species of juvenile mullet and its contribution to their growth. Mar Ecol Prog Ser 130:19-28

> Lombard F, Eloire D, Gobet A, Stemmann L, Dolan JR, Sciandra A, Gorsky G (2010) Experimental and modeling evidence of appendicularian-ciliate interactions. Limnol 
Oceanogr 55:77-90

Lyons MM, Dobbs FC (2012) Differential utilization of carbon substrates by aggregate-associated and waterassociated heterotrophic bacterial communities. Hydrobiologia 686:181-193

MacIntyre S, Alldredge AL, Gotschalk CC (1995) Accumulation of marine snow at density discontinuities in the water column. Limnol Oceanogr 40:449-468

Mackas DL, Denman KL, Abbott MR (1985) Plankton patchiness: biology in the physical vernacular. Bull Mar Sci 37: 652-674

Malkiel E, Abras JN, Widder EA, Katz J (2006) On the spatial distribution and nearest neighbor distance between particles in the water column determined from in situ holographic measurements. J Plankton Res 28: $149-170$

Matthäus W, Franck H (1992) Characteristics of major Baltic inflows - a statistical analysis. Cont Shelf Res 12: 1375-1400

> McManus MA, Alldredge AL, Barnard AH, Boss E and others (2003) Characteristics, distribution and persistence of thin layers over a 48 hour period. Mar Ecol Prog Ser 261: $1-19$

McManus MA, Cheriton OM, Drake PJ, Holliday DV, Storlazzi CD, Donaghay PL, Greenlaw CF (2005) Effects of physical processes on structure and transport of thin zooplankton layers in the coastal ocean. Mar Ecol Prog Ser 301:199-215

McManus MA, Kudela RM, Silver MV, Steward GF, Sullivan JM, Donaghay PL (2008) Cryptic blooms: Are thin layers the missing connection? Estuar Coasts 31:396-401

Möllmann C, Kornilovs G, Sidrevics L (2000) Long-term dynamics of main mesozooplankton species in the central Baltic Sea. J Plankton Res 22:2015-2038

> Newell CR, Pilskaln CH, Robinson SM, MacDonald BA (2005) The contribution of marine snow to the particle food supply of the benthic suspension feeder, Mytilus edulis. J Exp Mar Biol Ecol 321:109-124

Norrbin MF, Davis CS, Gallager SM (1996) Differences in fine-scale structure and composition of zooplankton between mixed and stratified regions of Georges Bank. Deep-Sea Res II 43:1905-1924

> Peters J, Renz J, van Beusekom J, Boersma M, Hagen W (2006) Trophodynamics and seasonal cycle of the copepod Pseudocalanus acuspes in the Central Baltic Sea (Bornholm Basin): evidence from lipid composition. Mar Biol 149:1417-1429

> Pilskaln CH, Villareal TA, Dennett M, Darkangelo-Wood C, Meadows G (2005) High concentrations of marine snow and diatom algal mats in the North Pacific Subtropical Gyre: implications for carbon and nitrogen cycles in the oligotrophic ocean. Deep-Sea Res I 52:2315-2332

> Pinel-Alloul B (1995) Spatial heterogeneity as a multiscale characteristic of zooplankton community. Hydrobiologia 300-301:17-42

> Renz J, Hirche HJ (2006) Life cycle of Pseudocalanus acuspes Giesbrecht (Copepoda, Calanoida) in the Central Baltic Sea: I. Seasonal and spatial distribution. Mar Biol 148:567-580

Sevadjian JC, McManus MA, Pawlak G (2010) Effects of physical structure and processes on thin zooplankton layers in Mamala Bay, Hawaii. Mar Ecol Prog Ser 409: 95-106

Editorial responsibility: Marsh Youngbluth, Fort Pierce, Florida, USA
Shanks AL (2002) The abundance, vertical flux, and stillwater and apparent sinking rates of marine snow in a shallow coastal water column. Cont Shelf Res 22: 2045-2064

- Shanks AL, del Carmen KA (1997) Larval polychaetes are strongly associated with marine snow. Mar Ecol Prog Ser 154:211-221

- Shanks AL, Edmondson EW (1990) The vertical flux of metazoans (holoplankton, meiofauna, and larval invertebrates) due to their association with marine snow. Limnol Oceanogr 35:455-463

Shanks AL, Walters K (1996) Feeding by a heterotrophic dinoflagellate (Noctiluca scintillans) in marine snow. Limnol Oceanogr 41:177-181

> Shanks AL, Walters K (1997) Holoplankton, meroplankton, and meiofauna associated with marine snow. Mar Ecol Prog Ser 156:75-86

> Silver MW, Gowing MM, Brownlee DC, Corliss JO (1984) Ciliated protozoa associated with oceanic sinking detritus. Nature 309:246-248

Steinberg DK (1995) Diet of copepods (Scopalatum vorax) associated with mesopelagic detritus (giant larvacean houses) in Monterey Bay, California. Mar Biol 122: 571-584

Stemmann L, Boss E (2012) Plankton and particle size and packaging: from determining optical properties to driving the biological pump. Annu Rev Mar Sci 4:263-290

> Stemmann L, Picheral M, Gorsky G (2000) Diel variation in the vertical distribution of particulate matter $(>0.15 \mathrm{~mm})$ in the NW Mediterranean Sea investigated with the Underwater Video Profiler. Deep-Sea Res I 47:505-531

> Stemmann L, Prieur L, Legendre L, Taupier-Letage I, Picheral M, Guidi L, Gorsky G (2008) Effects of frontal processes on marine aggregate dynamics and fluxes: an interannual study in a permanent geostrophic front (NW Mediterranean). J Mar Syst 70:1-20

> Sullivan JM, Donaghay PL, Rines JEB (2010a) Coastal thin layer dynamics: consequences to biology and optics. Cont Shelf Res 30(Spec Issue):50-65

Sullivan JM, McManus MA, Cheriton OM, Benoit-Bird KJ and others (2010b) Layered organization in the coastal ocean: an introduction to planktonic thin layers and the LOCO project. Cont Shelf Res 30(Spec Issue):1-6

> Tang XO, Stewart WK, Vincent L, Huang H, Marra M, Gallager SM, Davis CS (1998) Automatic plankton image recognition. Artif Intell Rev 12:177-199

- Tiselius P (1992) Behavior of Acartia tonsa in patchy food environments. Limnol Oceanogr 37:1640-1651

> Widder EA, Johnsen S, Bernstein SA, Case JF, Neilson DJ (1999) Thin layers of bioluminescent copepods found at density discontinuities in the water column. Mar Biol 134:429-437

Williamson CE, Stoeckel ME (1990) Estimating predation risk in zooplankton communities: the importance of vertical overlap. Hydrobiologia 198:125-131

Wilson SE, Steinberg DK (2010) Autotrophic picoplankton in mesozooplankton guts: evidence of aggregate feeding in the mesopelagic zone and export of small phytoplankton. Mar Ecol Prog Ser 412:11-27

> Woodson CB, MacManus MA (2007) Foraging behavior can influence dispersal of marine organisms. Limnol Oceanogr 52:2701-2709

Submitted: November 22, 2011; Accepted: August 3, 2012

Proofs received from author(s): October 31, 2012 